\title{
The Peritoneal Immune System and Continuous Ambulatory Peritoneal Dialysis
}

\author{
Jayson Rapoport ${ }^{a}$ Michael J. Hausmann ${ }^{b}$ Cidio Chaimovitz ${ }^{b}$ \\ aDepartment of Nephrology and Hypertension, Kaplan Medical Center, Rehovot, bepartment of Nephrology, \\ Soroka Medical Center and the Faculty of Health Sciences, Ben-Gurion University of the Negev, Beersheva, Israel
}

\section{Introduction}

Continuous ambulatory peritoneal dialysis (CAPD) has been an established treatment for end-stage renal disease for about 20 years. A major problem of CAPD is the relatively high incidence of peritonitis, and this fact has served as a stimulus to nephrologists to study the immune mechanisms of the peritoneum. It is by now well established that all three main cell systems present in the peritoneal cavity, namely, macrophages, lymphocytes and mesothelium, are involved in the initial peritoneal immune response, resulting in a massive recruitment of leucocytes from the peripheral blood, via the mesothelial cell layer, into the peritoneal cavity. However, this mechanism is adversely affected by the presence of commercial dialysis solution (CDS), which is highly unphysiological, in the peritoneal cavity. These processes are the subject of this review.

\section{Peritoneal Macrophages (PMФ)}

There is normally only a small volume of fluid, approximately $100 \mathrm{ml}$, in the peritoneal cavity. In CAPD, due to the constant presence of at least 2 liters of dialysate in the abdominal cavity, the resident macrophages are diluted, so that their concentration falls from a usual value of about $5 \times 10^{5}$ to $10^{6} / \mathrm{ml}$ to as low as $10^{3}$ to $10^{4} / \mathrm{ml}$ [1]

\begin{tabular}{ll}
\hline KARGER & ( ) 1999 S. Karger AG, Basel \\
Fax +4161306 12 34 & \\
$\begin{array}{l}\text { E-Mail karger@karger.ch } \\
\text { www.karger.com }\end{array}$ & Accessible online at: \\
http://BioMedNet.com/karger
\end{tabular}

These cells have traditionally been viewed as the first line of defence against invasion of micro-organisms in the peritoneum, but due to their dilution, there is a low probability of macrophage-bacteria interaction. They also possess functional immunophenotypic and cytochemical features which are not possessed by normal PM $\Phi$ [1-4]. This has led some investigators to propose that PМФ of CAPD patients are immature cells, reflecting the influx of younger monocytes due to the rapid turnover of the peritoneal cells $[2,5]$. However, other studies suggest that these cells are phagocytes stimulated by a state of chronic inflammation in the peritoneal cavity. It has been suggested that the CDS used in CAPD induces a state of chronic sterile inflammation in the peritoneal cavity, thereby activating the macrophages [5-9]. It is of course possible that PMФ are both immature and activated. Thus, Betjes et al. [10] found in a longitudinal study that PMФ after a year of CAPD revealed a less mature phenotype as measured by RFD7 expression, but increased phagocytic activity.

There is some controversy regarding the functional capacity of macrophages harvested after an intraperitoneal infusion of CDS. Davies et al. [3] and Peterson et al. [11] demonstrated that the ability to mount a phagocytic respiratory burst by stimulated $\mathrm{PM} \Phi$ was greater for CAPD patients than for normal controls. On the other hand, other workers have found a normal or slightly decreased bactericidal capacity of dialysis-elicited macrophages compared to PMФ from healthy controls [2, 12].
Prof. J. Rapoport

Department of Nephrology and Hypertension

Kaplan Medical Center, PO Box 1

Rehovot 76100 (Israel)

Tel. +97289441381, Fax +97289411104 
Since the macrophages are so diluted by the dialysis fluid, it seems highly likely that their antibacterial efficacy is accomplished largely by virtue of the production of potent inflammatory cytokines such as interleukin (IL) 1 and tumour necrosis factor alpha (TNF- $\alpha$ ). These cytokines interact with and stimulate other peritoneal resident cells, such as leucocytes and peritoneal mesothelial cells. However, there is no doubt that CDS exerts an inhibitory effect on the release of cytokines by $P M \Phi[13,14]$, and this fact is probably of considerable clinical importance. It is discussed in the final section.

Phenotypic changes in PM $\Phi$ also occur with time on CAPD. Thus, a $40-50 \%$ reduction in the expression of CD11b, CD16, CD64 and CD14 on PMФ was found during the course of treatment [15]. These changes could impair phagocytic functions, such as Fc receptor mediated phagocytosis (reduction in expression of CD11b, CD16, CD64) and phagocyte adhesion to the mesothelium (CD11b and CD14).

The interaction between vitamin D and PM $\Phi$ is of interest. We have shown that PMФ from CAPD patients are capable of metabolizing 25-hydroxyvitamin D to $1,25-(\mathrm{OH})_{2} \mathrm{D}_{3}$ in vitro [16]. This property was not found in PMФ from normal subjects, but incubation of normal PM $\Phi$ with peritoneal effluent from CAPD patients induced the ability in these cells to metabolize vitamin D. This ability may be related to the bactericidal activity of PM $\Phi$, since it was found that incubation of normal PM $\Phi$ with $1,25(\mathrm{OH})_{2} \mathrm{D}_{3}$ caused a significant twofold increase in superoxide generation in response to phorbol myristate acetate and enhanced bactericidal activity [17]. Interestingly, PM $\Phi$ from patients with a high incidence of peritonitis showed a low bactericidal activity and were not affected by $1,25(\mathrm{OH})_{2} \mathrm{D}_{3}$ after $24 \mathrm{~h}$ of treatment. However, РМФ from patients with a low incidence of peritonitis behaved similarly to those of normal subjects in their response to vitamin D. An important clinical finding was that normalization of serum levels of $1,25(\mathrm{OH})_{2} \mathrm{D}_{3}$ in CAPD patients by oral administration of this metabolite caused a significant increase in the ability of PM $\Phi$ and peripheral blood monocytes to produce superoxide [18].

\section{Mesothelial Cells}

These are the most abundant cells of the peritoneal cavity. They are no longer regarded as a passive lining membrane, and there is no doubt that they play an active role in the immune response. This is hardly surprising, since they are situated between the peritoneal cavity, containing macrophages and lymphocytes, and the underlying mesothelial microvasculature. They play a major role in the recruitment of leucocytes from the blood to the peritoneum. They are a target for macrophage-related cytokines and themselves produce cytokines, chemokines and adhesion molecules which result in migration of leucocytes from submesothelial capillaries across the mesothelium and into the peritoneal cavity. Thus human peritoneal mesothelial cells (HPMC) in culture produce IL-1 $\alpha$ and IL-1 $\beta$ when stimulated by Escherichia coli lipopolysaccharide (LPS), TNF- $\alpha$ or IL-1 $\alpha$, either singly or by LPS combined with any of these cytokines [19]. The combination of LPS with one of the cytokines causes a greatly enhanced effect, perhaps mimicking the events occurring during bacterial peritonitis. The main TNF receptor expressed on HPMC was shown to be TNF-R1 (p55) [20]. IL-1 induced downregulation of this receptor, concomitant with accumulation of soluble TNF-R1, presumably because of increased shedding of the receptor. LPS had a lower TNF-R1-shedding activity, while TNF- $\alpha$ did not induce shedding. Since the released receptors are believed to specifically bind TNF, thus preventing binding to the cell surface TNF receptor, these effects on the accumulation of soluble TNF-R1 may have an important impact on the inflammatory response of HPMC. In addition to IL-1, HPMC have also been shown to produce the important proinflammatory cytokine IL-6 [21, 22] and the chemokines IL-8 [21, 23], MCP-1 and RANTES [24]. In addition, Topley et al. [25] showed that HPMC stimulated by IL-1 $\beta$ or TNF- $\alpha$ released 6-keto-PGF $1 \alpha$. Incubation of HPMC in medium conditioned by PMФ increased release of 6-keto- $\mathrm{PGF}_{1 \alpha}$ and $\mathrm{PGE}_{2}$ [25]. Intraperitoneal vaso-active prostaglandins play a role in the inflammatory process by increasing the permeability of the peritoneal membrane to plasma proteins $[26,27]$ and by inhibiting cytokine release from inflammatory cells by a negative feedback mechanism [28, 29]. Thus the ability of HPMC to produce prostaglandins when stimuated by cytokines or by РМ $\Phi$ may be an important part of the peritoneal inflammatory process.

Thus stimulated peritoneal mesothelial cells are capable of producing IL-1 which, on the one hand, can amplify macrophage inflammatory signals and, on the other hand, is an important modulator of vascular endothelial cell function (via stimulation of prostaglandin production) and thus might interact in a paracrine fashion with the neighbouring peritoneal capillary network. As a consequence, the endothelial cells will be stimulated to participate in the inflammatory process by synthesizing vasodi- 
latory molecules and neutrophil chemotactic peptides and by expressing adhesion molecules. As a result, more inflammatory cells will be recruited [30-33].

An early prerequisite of the inflammatory response is the expression of adhesion molecules which regulate leucocyte-endothelial cell adhesion $[33,34]$. These molecules facilitate both adhesion to endothelial surface and transendothelial migration of leucocytes at the site of inflammation. After crossing the peritoneal capillary wall, the migrating leucocytes must also cross the mesothelial cell layer to reach the infected peritoneum. There is evidence that adhesion molecules are expressed on the membranes of mesothelial cells. These cells have been shown to constitutively express ICAM-1 and VCAM-1/2 [21, 33-37] which can be induced by PM $\Phi$-induced cytokines IL-1 and TNF- $\alpha[36]$.

An important question regarding HPMC is whether they are capable of functioning as antigen-presenting cells, thus activating peritoneal helper (CD4) lymphocytes. Hausmann et al. [submitted] performed a flow cytometry analysis of HPMC and found that HPMC expressed HLA-DR molecules following interferon- $\gamma$ (IFN- $\gamma$ ) treatment. ICAM-1 molecules were constitutively expressed at high levels, and B7-1 and B7-2 molecules could not be detected. The accessory function of HPMC was assayed by $\mathrm{T}$ cell stimulation using anti-CD3 antibodies (OKT3) in the presence or absence of HPMC. The presence of HPMC was essential for significant T cell proliferation. Anti-ICAM-1 antibodies blocked OKT3-induced proliferation, suggesting that ICAM-1 is the major accessory molecule on HPMC. HPMC served as effective antigen-presenting cells when tetanus toxoid or Staphylococcus aureus alpha toxin was used as antigen.

We also studied the secretion of IL-15 by HPMC [Douvdevani et al., submitted]. IL-15 shares two subunits of the IL-2 receptor and is a potent T cell activator [38, 39]. IFN- $\gamma$ upregulated IL-15 mRNA levels and IL-15 protein secretion by HPMC. We analyzed IL-15 levels in the dialysis effluent of CAPD patients. High levels were detected in the effluent of patients suffering from peritonitis and low levels in non-infected patients.

It thus seems that HPMC actively participate in the peritoneal immune response against an invading pathogen by antigen presentation to helper $T$ cells and by secretion of IL-15, a T cell activator and growth factor.

\section{Peritoneal Lymphocytes (Ply)}

Few studies have been devoted to Ply and their possible role in the immune response to infection, but their importance has become increasingly realized in recent years. As with PMФ and HPMC, there is a significant impact of CAPD on composition and function of Ply.

Data in healthy subjects regarding the normal concentration of Ply are conflicting. Earlier studies in normal subjects report that a mean of $5-10 \%$ of peritoneal cells consists of lymphocytes compared to $20 \%$ in peripheral blood. Within the first month of CAPD treatment, Ply increase to $20-30 \%$ of peritoneal cells. Thereafter, the lymphocyte number increases only slightly over time, except for transient increases following episodes of acute peritonitis, returning to baseline values within 1-2 months. However, the lymphocyte number does not correlate with the incidence rate of peritonitis [40].

In a more recent study on women undergoing diagnostic laparoscopy, $30 \%$ of the cells in peritoneal lavage fluid were lymphocytes [41]. In the omentum and under the parietal peritoneum $\mathrm{T}$ cells and $\mathrm{B}$ cells aggregate within milky spots, contributing $10 \%$ each to the total cell number [42]. $\mathrm{T}$ cells are also organized perivascularly within the peritoneum [43], while the omentum has been found to be a site of B cell (CD5) generation during human fetal life [44].

Several publications support the concept that the peritoneal cavity of the healthy subject harbours a micro-environment which, compared to peripheral blood, favours several different subsets of lymphocytes [45]. The majority of lymphocytes are CD3+ $\mathrm{T}$ cells in both compartments, but $12 \%$ of peripheral lymphocyte stain as B cells, whereas only $2.3 \%$ of peritoneal lymphocytes are B cells. Within the $\mathrm{CD} 3+\mathrm{T}$ cell population, the $\mathrm{CD} 4 / \mathrm{CD} 8$ ratio is inverted from $1.7-2$ in peripheral blood to 0.5 in the peritoneum, reflecting both a decrease in $\mathrm{T}$ helper cell number and an increase in cytotoxic T cell number [40]. 92\% of CD4+ cells and $73 \%$ of CD8+ cells express the CD45RO isoform of CD45. CD45RO is characteristic of memory/ effector T cells and is expressed in 50 and $30 \%$ of peripheral CD4+ and CD8+ cells, respectively [46]. Natural killer (NK) cells are enriched in the peritoneal cavity compared to peripheral blood, thus, $10 \%$ of peripheral lymphocytes are CD3- compared to $26 \%$ in the peritoneum. $80 \%$ of all peritoneal CD3- cells stain as NK cells, and $16 \%$ of peritoneal CD3- cells stain as CD8+ NK cells [40]. A further striking difference is a peritoneal subpopulation of CD3- cells bearing one of two phenotypic traits of thymus-independent $\mathrm{T}$ cells [47]: $60 \%$ of peritoneal 
CD3-/CD8+ cells express the $\mathrm{CD} 8 \alpha^{+} \beta^{-}$homodimer $(>2.5 \%$ in peripheral blood), whereas another CD3- subpopulation expresses the recombination-activating gene RAG-1 [41]. B-1 cells have been shown to move between the peritoneum and the gut [48]. Similarly, Th2-type CD8+ cells have been identified in intestinal Peyer's patches [49] and normal human peritoneum [50]. It is thus possible that intestine and peritoneum form a common pool of thymus-independent $T$ cells.

The functional significance of the increased number of CD8+ cells in the healthy peritoneum has been addressed. The majority of peritoneal CD8+ cells secrete the Th1 pattern of cytokines, i.e., IL-2, IFN- $\gamma$ and TFN- $\alpha$ which are cytotoxic. Some of the peritoneal CD8+ cells were found to secrete IL-4 and IL-5 characteristic of Th2 cells. These Th2-type cells are able to support B cell differentiation and secretion of IgG and $\operatorname{IgA}$, but have no cytotoxic activity [50].

The factors responsible for the specific micro-environment in the peritoneal cavity remain to be determined. It can be anticipated that locally produced cytokines contribute to the attraction and/or maturation of peritoneal lymphocytes. IL-15 has been characterized in recent years as a cytokine produced by macrophages and stromal cells. This cytokine has, among other actions, a specific effect on maturation of murine NK cells [39]. Since NK cells are represented in the peritoneal cavity in greater proportions than in peripheral blood, IL-15 would seem to be a suitable candidate cytokine contributing to the buildup of the particular peritoneal lymphocyte population. HPMC in culture produce IL-15 both constitutively and in response to stimulation by IFN- $\gamma$. Furthermore, IL-15 has been detected in the dialysis effluent of CAPD patients [Douvdevani et al., submitted].

Thus Ply seem to provide the healthy peritoneal cavity with a specific capacity of defence against potential infection. This capacity is impaired in CAPD patients, since the total number of Ply is reduced by $85 \%$ [51], and thymus-independent $\mathrm{T}$ cells are no longer detectable among Ply [52]. In addition, Ply from CAPD patients with a high incidence of peritonitis showed a decreased capacity to secrete IFN- $\gamma$ as compared with CAPD patients with a low incidence of peritonitis [53]. This may reflect the known impairment by uraemia of lymphopoiesis [54]. Alternatively, because of their limited biocompatibility, dialysis solutions may induce a more general response of the peritoneum to CAPD. Over time, the composition of the peritoneal cell population changes, eventually reaching a similar composition to that of peripheral blood. CDS is detrimental to mesothelial cell function, and several studies have shown that mesothelial cell number decreases with ongoing peritoneal dialysis [55, 56]. Given the finding that HPMC secrete IL-15, we may speculate that the change in composition of the Ply population in CAPD patients is due, at least in part, to reduced mesothelial production of IL-15.

\section{Effect of CDS on the Peritoneal Immune Response}

As described above, the peritoneal immune response is well developed, and the question may be asked as to why the peritoneum is so vulnerable to infection in CAPD. A possible answer to this question is that the peritoneum of CAPD patients is exposed to at least 8 litres of CDS daily. CDS is a highly unphysiological solution with a $\mathrm{pH}$ of about 5.3 and high lactate and glucose concentrations. When human PMФ were exposed to CDS, a profound impairment in bacterial phagocytosis, a blunted respiratory burst response and a strong inhibition of cytokine production were all observed [13, 14]. These abnormalities can be avoided if the $\mathrm{pH}$ is raised from 5.3 to 7.4. However, the low $\mathrm{pH}$ itself does not seem to be detrimental, and it was only after addition of lactate that functional abnormalities of the cells became evident [13]. The effect of lactate on PМФ was studied in detail by Douvdevani et al. [57], using intracellular $\mathrm{pH}\left(\mathrm{pH}_{\mathrm{i}}\right)$ clamping of PMФ by means of $\mathrm{K}^{+} /$nigericin. CDS always caused a greater intracellular acidification than HEPES-buffered salt solution at the same $\mathrm{pH}$, and this effect was mimicked by lactate. Thus the decrease in $\mathrm{pH}_{\mathrm{i}}$ caused by CDS was due to influx of lactic acid from the CDS into the PMФ. A causal association was then shown between the CDS-induced cellular acidification and a defect in phagocytosis and cytokine production. Clamping $\mathrm{pH}_{\mathrm{i}}$ values to below 6.5 led to a markedly reduced TNF- $\alpha$ production and phagocytosis. However, at values $>6.5$, these functions were normal. In a further study, Rogachev et al. [58] analyzed the effect of CDS on TNF- $\alpha$ production by LPS-stimulated human peripheral blood macrophages. CDS lowered TNF- $\alpha$ mRNA levels within 15 min of exposure of cells to CDS. In addition, CDS inhibited the DNA-binding activity of $\mathrm{NF}-\kappa \mathrm{B}$ which is probably involved in regulation of LPSmediated transcriptional activation of the TNF- $\alpha$ gene. Inhibition was dependent on both the low $\mathrm{pH}$ and lactate of the CDS, but was independent of the osmolarity and glucose concentration. Thus, impairment of LPS-stimulated TNF- $\alpha$ expression by PMФ may be the result of a low activity of NF- $\kappa \mathrm{B}$. Since $\mathrm{NF}-\kappa \mathrm{B}$ is involved in the 
transcription regulation of a large number of 'early activation' genes, CDS may interfere with the production of additional immunomodulatory proteins that are encoded by genes possessing NF- $\mathrm{\kappa B}$ site(s) in their promoter region.

Thus the low $\mathrm{pH}$ and the high lactate concentration of CDS are undoubtedly detrimental to the normal peritone- al immune defences. Development of new solutions using bicarbonate as buffer would be more physiological and would be likely to interfere less with these mechanisms, with a resultant improvement in the incidence of peritonitis.

\section{References}

1 Holmes C: Peritoneal host defence mechanisms in peritoneal dialysis. Kidney Int 1994; 46(suppl 48):58-70.

2 Goldstein CS, Bomalaski JS, Zurier RB, Neilson EG, Douglas SD: Analysis of peritoneal macrophages in continuous ambulatory peritoneal dialysis. Kidney Int 1984;26:733-740.

3 Davies SJ, Suassuna J, Ogg CS, Cameron JS: Activation of immunocompetent cells in the peritoneum of patients treated with CAPD. Kidney Int 1989;36:661-668.

4 Bos HJ, Sruijk DG, Tuk CW, Beelen RHJ: Characterization of peritoneal cells from continuous ambulatory peritoneal dialysis (CAPD) patients: An immunological and functional study. J Leukoc Biol 1989;46:313.

5 McGregor SJ, Topley N, Jorres A, Speekenbrink AB, Gordon A, Gahl GM, Junor BJ, Briggs JD, Brock JH: Longitudinal evaluation of peritoneal macrophage function and activation during CAPD: Maturity, cytokine synthesis and arachidonic acid metabolism. Kidney Int 1996;49:525-533.

6 Lewis S, Holmes CJ: Host defence mechanisms in the peritoneal cavity of continuous ambulatory peritoneal dialysis patients. Perit Dial Int 1991;11:14-21.

7 Bos HJ, Meyer F, de Veld JC, Beelen RHJ: Peritoneal dialysis fluid induces changes of mononuclear phagocytic proportion. Kidney Int 1989;36:20-26.

8 Bos HJ, van Bronswijk H, Helmerhorst TJM, Oe PL, Hoefsmit ECM, Beelen RHJ: Distinct subpopulation of elicited human macrophages in peritoneal dialysis patients and women undergoing laparoscopy: A study on peroxidatic activity. J Leukoc Biol 1988;43:172-178.

9 Bos HJ, Struijk DG, Tuk CW, de Weld JC, Helerhorst TJM, Hoefsmit ECM, Arisz L, Beelen RHJ: Peritoneal dialysis induces a local sterile inflammatory state and the mesothelial cells in the affluent are related to the bacterial peritonitis incidence. Nephron 1991;59:508-509.

10 Betjes MGH, Tuk CW, Struijk DJ, Krediet RT, Arisz L, Hoefsmit ECM, Beelen RHJ: Immuno-effector characteristics of peritoneal cells during CAPD treatment: A longitudinal study. Kidney Int 1993;43:641-648.

11 Peterson PK, Gaziano E, Suh HJ, Devalon M, Peterson L, Keane WK: Antimicrobial activities of dialysate-elicited and resident human peritoneal macrophages. Infect Immun 1985; 49:212-218.
12 McGregor SJ, Brock JH, Briggs JD, Junor BJR: Bactericidal activity of peritoneal macrophages from CAPD patients. Nephrol Dial Transplant 1987;2:104-108.

13 Douvdevani A, Rapoport J, Konforti A, Zlotnik M, Chaimovitz C: The effect of peritoneal dialysis solution on the release of IL-1 $\beta$ and $\mathrm{TNF} \alpha$ by peritoneal macrophages. Perit Dial Int 1993;13:112-117.

14 Douvdevani A, Abramson O, Tamir A, Konforty A, Isakov $\mathrm{N}$, Chaimovitz C: Commercial dialysate inhibits TNF $\alpha$ mRNA expression and NK- $\kappa B$ DNA binding activity in LPS-stimulated macrophages. Kidney Int 1995;47:15371545.

15 Carcamo C, Fernandez-Castro M, Selgas R, Jimenez C, Molina S, Vara F: Long-term continuous ambulatory peritoneal dialysis reduces the expression of CD11b, CD14 and CD64 on peritoneal macrophages. Perit Dial Int 1996; 16:582-659.

16 Shany S, Rapoport J, Zuili I, Gavriel A, Lavi N, Chaimovitz C: Metabolism of 25-OH-vitamin $\mathrm{D}_{3}$ by peritoneal macrophages from CAPD patients. Kidney Int 1991;39:1005-1011.

17 Levy R, Klein J, Rubinek T, Alkan M, Shany S, Chaimovitz C: Diversity in peritoneal macrophage response of CAPD patients to 1,25-dihydroxyvitamin $\mathrm{D}_{3}$. Kidney Int 1990;37:13101315 .

18 Deutsch A, Zlotnik M, Chaimovitz C, Levy R: Increased superoxide generation in phagocytes of patients undergoing continuous ambulatory peritoneal dialysis by in vivo treatment of 1,25 dihydroxyvitamin $\mathrm{D}_{3}$. Eur J Haematol 1994; 24:A40.

19 Douvdevani A, Rapoport J, Konfort A, Argov S, Ovnat A, Chaimovitz C: Human peritoneal mesothelial cells synthesize IL-1 alpha and beta. Kidney Int 1994;46:993-1001.

20 Douvdevani A, Einbinder T, Yulzari R, Rogachov B, Chaimovitz C: TNF receptors on human peritoneal mesothelial cells: Regulation of receptor levels and shedding by IL- $1 \alpha$ and TNF $\alpha$. Kidney Int 1996;50:219-228.

21 Jonjic N, Peri G, Bernasconi S, Sciacca FL, Colotta F, Pelicci PG, Lanfrancone L, Mantovani A: Expression of adhesion molecules and chemotactic cytokines in cultured human mesothelial cells. J Exp Med 1992;176:11651174 .
22 Topley N, Jorres A, Luttman W, Petersen MM, Lang MJ, Thierauch KH, Muller C, Coles GA, Davies M, Wiliams JD: Human peritoneal mesothelial cells synthesize interleukin-6: Induction by IL-1 $\beta$ and TNF $\alpha$. Kidney Int 1993;43: 226-233.

23 Topley N, Brown Z, Jorres A, Westwick J, Davies M, Coles GA, Williams JD: Human peritoneal mesothelial cells (HPMC) synthesize interleukin 8 (IL-8): Synergistic induction by interleukin-1 $\beta$ and tumor necrosis factor $\alpha$. Am J Pathol 1993;142:1876-1886.

24 Topley N, Mackenzie R, Williams JD: Macrophages and mesothelial cells in bacterial peritonitis. Immunobiology 1996;195:563-573.

25 Topley N, Petersen MM, Mackenzie R, Neubauer A, Stylianou E, Kaever V, Davies M, Coles GA, Jorres A, Williams JD: Human peritoneal mesothelial cell prostaglandin synthesis: Induction of cyclooxygenase mRNA by peritoneal macrophage-derived cytokines. Kidney Int 1994;46:900-909.

26 Steinbauer HB, Gunter B, Schollmeyer P: Stimulation of peritoneal synthesis of vasoactive prostaglandins during peritonitis in patients on continuous ambulatory peritoneal dialysis. Eur J Clin Invest 1985;15:1-5.

27 Steinbauer HB, Schollmeyer P: Prostaglandinmediated loss of proteins during peritonitis in continuous ambulatory peritoneal dialysis. Kidney Int 1986;29:584-590.

28 Knudsen PJ, Dinarello CA, Strom TB: Prostaglandins post-transcriptionally inhibit monocyte expression of interleukin-1 activity by increasing intracellular cAMP. J Immunol 1988; 137:3189-3194.

29 Kunkel SL, Chensue SW: Arachidonic acid metabolites regulate interleukin-1 production. Biochem Biophys Res Commun 1985;128: 892-897.

30 Kolb H, Kolb-Bachofen V: Nitric oxide: A pathogenic factor in autoimmunity. Immunol Today 1992;13:157-160.

31 Zimmerman GA, Prescott SM, McIntyre TM: Endothelial cell interactions with granulocytes: Tethering and signalling molecules. Immunol Today 1992;13:93-99.

32 Pardi R, Inverardi L, Bender JR: Regulatory mechanisms in leucocyte adhesion: Flexible receptors for sophisticated travelers. Immunol Today 1992;13:224-230. 
33 Mantovani A, Dejana E: Cytokines as communication signals between leucocytes and endothelial cells. Immunol Today 1989;10:370375.

34 Smith CW, Kishimoto TK, Abrass O, Hughes B, Rothlein R, McIntyre LV, Butcher E, Anderson DC: Chemotactic factors regulate lectin adhesion molecule 1 (LECAM-1)-dependent neutrophil adhesion to cytokine-stimulated endothelial cells in vitro. J Clin Invest 1991;87: 609-618.

35 Cannistra SA, Ottensmeier C, Tidy J, Defranzo $\mathrm{B}$ : Vascular cell adhesion molecule- 1 expressed by peritoneal mesothelium partly mediates the binding of activated human $\mathrm{T}$ lymphocytes. Exp Hematol 1994;22:996-1002.

36 Liberek T, Topley N, Luttmann W, Williams JD: Adherence of neutrophils to human peritoneal mesothelial cells: Role of intercellular adhesion molecule-1. J Am Soc Nephrol 1996;7 208-217.

37 Andreoli SP, Mallett C, Williams K, McAteer JA, Rothlein R, Doerschuk CM: Mechanisms of polymorphonuclear leukocyte mediated peritoneal mesothelial cell injury. Kidney Int 1994:46:1100-1109.

38 Cosman D, Kumaki S, Ahdieh M, Eisenman J, Grabstein KH, Paxton R, Dubose R, Friend D, Park LS, Anderson D: Interleukin 15 and its receptor. Ciba Found Symp 1995;195:221229.

39 Tagaya Y, Bamford RN, DeFilippis AR, Waldmann A: IL-15: A pleiotropic cytokine with diverse receptor/signalling pathways whose expression is controlled at multiple levels. Immunity 1996;4:329-336.

40 Lewis SL, Kutvirt CL, Cooper PN, Bonner PN, Holmes CJ: Characteristics of peripheral and peritoneal lymphocytes from continuous ambulatory peritoneal dialysis patients. Perit Dia Int 1993;13(suppl 2):273-277.
41 Hartman J, Maasen V, Rieber P, Fricke H: T lymphocytes from normal human peritoneum are phenotypically different from their counterparts in peripheral blood and CD3- lymphocyte subsets contain mRNA for the recombination activating gene RAG-1. Eur $\mathrm{J}$ Immunol 1995;25:2626-2631.

42 Krist LF, Eestermans IL, Steenbergen JJ, Hoefsmit EC, Cuesta MA, Meyer S, Beelen $\mathrm{RH}$ : Cellular composition of milky spots in the human greater omentum: An immunochemical and ultrastructural study. Anat Rec 1995;241: 163-174.

43 Suassuna JH, Das Neves FC, Hartley RB, Ogg CS, Cameron JS: Immunohistochemical studies of the peritoneal membrane and infiltrating cells in normal subjects and in patients on CAPD. Kidney Int 1994;46:443-454.

44 Solvason N, Kearney JF: The human fetal omentum: A site of B-cell generation. J Exp Med 1992;175:397-404.

45 Hayakawa K, Hardy RR: Murine CD4+ T-cell subsets. Immunol Rev 1991;123:145-168.

46 Kubicka U, Olszewski WL, Tarnovski W, Bielecki K, Zielkowska A, Wierzbicki Z: Normal human immune peritoneal cells: Subpopulations and functional characteristics. Scand J Immunol 1996;44:157-163.

47 Poussier P, Julius M: Thymus-independent T cell development and selection in the intestinal epithelium. Annu Rev Immunol 1994;12:521553.

48 Murakami M, Honjo T: Involvement of B-1 cells in mucosal immunity and autoimmunity. Immunol Today 1995;16:534-539.

49 Lagoo AS, Eldridge JH, Lagoo-Deenadaylan S, Black CA, Ridwan BU, Hardy KJ, McGhee JR, Beagley KW: Peyer's patch CD8+ memory T cells secrete $\mathrm{T}$ helper type 1 and type 2 cytokines and provide help for immunoglobulin secretion. Eur J Immunol 1994;24:3087-3092.

50 Birkhofer A, Rehbock J, Fricke T: T lymphocytes from the normal human peritoneum contain high frequencies of Th2-type CD8+ T cells. Eur J Immunol 1996;26:957-960.
51 Donze HH, Lue C, Julian BA, Kutteh WH, Kantele A, Mestecky J: Human peritoneal B-1 cells and the influence of continuous ambulatory peritoneal dialysis on peritoneal and peripheral blood mononuclear cell (PBMC) composition and immunoglobulin levels. Clin Exp Immunol 1997;109:356-361.

52 Fricke H, Hartmann T, Sitter T, Steldinger R, Rieber P, Schiffl H: Continuous ambulatory peritoneal dialysis impairs T lymphocyte selection in the peritoneum. Kidney Int 1996;49: 1386-1395.

53 Lamperi S, Carozzi S: Interferon-gamma (IFNgamma) as an in vitro enhancing factor of peritoneal macrophage defective bactericidal activity during continuous ambulatory peritoneal dialysis (CAPD). Am J Kidney Dis 1988;11: 225-230.

54 Chatenoud L, Jungers P, Descamps-Latscha B: Immunological considerations of the uremic and dialyzed patient. Kidney Int 1994; 45(suppl 44):92-96.

55 Gotloib L, Shostak A, Wajsbrot V: Detrimental effects of peritoneal dialysis solutions upon in vivo and in situ exposed mesothelium. Perit Dial Int 1997;17(suppl 2):13-16.

56 Ho-Dac-Pannekeet MM, Hiralall JK, Struijk DG, Krediet RT: Longitudinal follow-up of CA125 in peritoneal effluent. Kidney Int 1997; 51:888-893

57 Douvdevani A, Rapoport J, Konforti A, Yulzari R, Moran A, Chaimovitz C: Intracellular acidification mediates the inhibitory effect of peritoneal dialysate on peritoneal macrophages. J Am Soc Nephrol 1995;6:207-213.

58 Rogachev B, Hausmann MJ, Yulzari R, Weiler M, Holmes C, Falc D, Chaimovitz C, Douvdevani $\mathrm{A}$ : Effect of bicarbonate-based solutions on intracellular $\mathrm{pH}\left(\mathrm{pH}_{\mathrm{i}}\right)$ and $\mathrm{TNF} \alpha$ production by peritoneal macrophages. Perit Dial Int 1997; 17:546-553. 